Article

\title{
Digital Logistics Platforms in the BRICS Countries: Comparative Analysis and Development Prospects
}

\author{
Sergey Evgenievich Barykin ${ }^{1,2, * \mathbb{C}}$, Irina Vasilievna Kapustina ${ }^{1}$, Elena Viktorovna Korchagina ${ }^{1}(\mathbb{C}$, \\ Sergey Mikhailovich Sergeev ${ }^{3}\left(\mathbb{D}\right.$, Vladimir Konstantinovich Yadykin ${ }^{2}\left({ }^{\circ}\right.$, Almakul Abdimomynova ${ }^{4}(\mathbb{D}$ \\ and Diana Stepanova ${ }^{5}$ (iD \\ 1 Graduate School of Service and Trade, Peter the Great St. Petersburg Polytechnic University, \\ 195251 Petersburg, Russia; ivk65@list.ru (I.V.K.); elena.korchagina@mail.ru (E.V.K.) \\ 2 National Technological Initiative Center, Peter the Great St. Petersburg Polytechnic University, \\ 195251 Petersburg, Russia; v.yadikin@gmail.com \\ 3 Graduate School of Industrial Management, Peter the Great St. Petersburg Polytechnic University, \\ 195251 Petersburg, Russia; sergeev2@yandex.ru \\ 4 Department of Economic Affairs, Korkyt Ata Kyzylorda University, Kyzylorda 120014, Kazakhstan; \\ abdim.alma@mail.ru \\ 5 Department of Finance and Prices, Plekhanov Russian University of Economics, 115903 Moscow, Russia; \\ s_diana@mail.ru \\ * Correspondence: sbe@list.ru
}

\section{check for}

updates

Citation: Barykin, S.E.; Kapustina, I.V.; Korchagina, E.V.; Sergeev, S.M.; Yadykin, V.K.; Abdimomynova, A.; Stepanova, D. Digital Logistics Platforms in the BRICS Countries: Comparative Analysis and Development Prospects. Sustainability 2021, 13, 11228. https://doi.org/ $10.3390 /$ su132011228

Academic Editors: Alexey Mikhaylov and Sebastian Kot

Received: 19 July 2021

Accepted: 23 September 2021

Published: 12 October 2021

Publisher's Note: MDPI stays neutral with regard to jurisdictional claims in published maps and institutional affiliations.

Copyright: (c) 2021 by the authors Licensee MDPI, Basel, Switzerland. This article is an open access article distributed under the terms and conditions of the Creative Commons Attribution (CC BY) license (https:/ / creativecommons.org/licenses/by/ $4.0 /)$.

\begin{abstract}
The BRICS Group unites the most rapidly developing large countries, the trade and economic interaction between which can make a significant contribution to both the region's and world's development. The purpose of this article is to analyze the development of trade and economic interaction and logistics infrastructure in the BRICS countries, as well as to develop an analytical concept of the BRICS Digital Logistics Platform (DLP) as a tool for the BRICS development. The research methodology includes methods for statistical data analysis, a case study of the DLP development in the BRICS countries, an analysis of the existing definitions and methods for developing DLP, and methods of systemic analysis. The research results present the trade and logistics interaction between the BRICS countries. The level of logistics development in these countries is analyzed based on the World Bank Logistics Performance Index. The article highlights the existing restrictions for the expansion of the economic interaction between countries, one of which is the uneven development of the logistics infrastructure. The article states that the BRICS DLP can be a tool for overcoming the limitation of uneven logistics infrastructure and intensifying trade interaction between the BRICS countries. The experience of creating national DLPs in each of the BRICS countries is analyzed. It is shown that the BRICS countries cannot join one of the existing national DLPs because of the risks for the national sovereignty of the participants. Therefore, an original analytical description for the international BRICS DLP is proposed. It will focus on the simplicity and transparency of the interaction between all of the participants of trade and economic interactions at various levels, as well as on the reduction of economic and logistics risks.
\end{abstract}

Keywords: digital logistics platforms (DLP); international trade; international logistics; logistics infrastructure; BRICS countries

\section{Introduction}

The BRICS is an informal interstate association of five countries: the Federative Republic of Brazil, the Russian Federation, the Republic of India, the People's Republic of China and the Republic of South Africa. The first four countries joined this association in 2006, and South Africa joined it in 2010. The BRICS countries have developing economies, high potential and significant influence in their regions. The BRICS countries' total population is 3.2 billion people, or $42 \%$ of the world's population, and their total area is 39.7 million $\mathrm{km}^{2}$, 
or $26 \%$ of the land surface area. According to the International Monetary Fund estimates, in 2019, the aggregate share of the BRICS countries in the world GDP at purchasing power parity was about $33 \%(24.2 \%$ at current prices). The exports of the five countries amounted to 3.6 trillion US dollars, which is $19 \%$ of world exports [1]. The main macroenvironmental indicators of the BRICS countries are presented in Table 1. It shows that the development of the BRICS countries is uneven. Chinese economic power leads to its domination in the BRICS group.

Table 1. The main macroenvironmental indicators of the BRICS countries, 2015-2019, adapted from [1].

\begin{tabular}{|c|c|c|c|c|c|c|c|c|c|c|c|c|c|c|c|}
\hline & \multicolumn{3}{|c|}{ Brazil } & \multicolumn{3}{|c|}{ Russia } & \multicolumn{3}{|c|}{ India } & \multicolumn{3}{|c|}{ China } & \multicolumn{3}{|c|}{ South Africa } \\
\hline & $1 *$ & 2 & 3 & 1 & 2 & 3 & 1 & 2 & 3 & 1 & 2 & 3 & 1 & 2 & 3 \\
\hline $\begin{array}{l}\text { Real GDP,\% to the } \\
\text { previous year }\end{array}$ & 3.6 & -1.1 & 0.9 & -2.3 & 1.6 & 1.1 & 8.0 & 7.2 & 6.1 & 6.9 & 6.8 & 6.1 & 1.2 & 1.4 & 0.7 \\
\hline $\begin{array}{l}\text { GDP nominal, trillion } \\
\text { USD }\end{array}$ & 1.8 & 2.1 & 1.8 & 1.4 & 1.6 & 1.6 & 2.1 & 2.7 & 2.9 & 11.2 & 12.1 & 14.1 & 0.3 & 0.3 & 0.4 \\
\hline $\begin{array}{l}\text { GDP per capita, PPP, } \\
\text { thousand USD (2011) }\end{array}$ & 14.9 & 14.3 & 14.4 & 24.6 & 25.0 & 25.9 & 5.9 & 6.6 & 7.3 & 13.5 & 15.2 & 17.0 & 12.3 & 12.2 & 12.0 \\
\hline $\begin{array}{c}\text { Accumulation rate, } \% \text { of } \\
\text { GDP }\end{array}$ & 17.4 & 15.0 & 15.7 & 22.4 & 24.1 & 23.1 & 32.1 & 30.9 & 31.3 & 44.7 & 44.6 & 43.4 & 20.9 & 18.8 & 17.6 \\
\hline $\begin{array}{c}\text { Average annual } \\
\text { inflation, } \%\end{array}$ & 9.0 & 3.4 & 3.8 & 15.5 & 3.7 & 4.7 & 4.9 & 3.6 & 3.4 & 1.4 & 1.6 & 2.3 & 4.6 & 5.3 & 4.4 \\
\hline $\begin{array}{c}\text { Population, billion } \\
\text { people }\end{array}$ & 0.2 & 0.21 & 0.21 & 0.15 & 0.15 & 0.15 & 1.28 & 1.32 & 1.35 & 1.37 & 1.39 & 1.4 & 0.05 & 0.06 & 0.06 \\
\hline $\begin{array}{c}\text { State budget balance, } \% \\
\text { of GDP }\end{array}$ & -10.3 & -7.9 & -7.5 & -3.4 & -1.5 & 1.0 & -7.2 & -7.0 & -7.5 & -2.8 & -3.9 & -6.1 & -4.8 & -4.4 & -6.2 \\
\hline Public debt, $\%$ of GDP & 35.6 & 51.6 & 58.1 & - & - & - & - & - & - & - & - & - & 43.6 & 47.8 & 55.3 \\
\hline $\begin{array}{l}\text { Current account, } \% \text { of } \\
\text { GDP }\end{array}$ & -3.0 & -0.4 & -1.2 & 5.0 & 2.1 & 5.7 & -1.1 & -1.8 & -2.0 & 2.7 & 1.6 & 1.0 & -4.6 & -2.5 & -3.1 \\
\hline
\end{tabular}

* 1 means 2015, 2 means 2017, and 3 means 2019.

The goal of the BRICS is to solve the BRICS countries' economic, financial and political problems. This goal can be achieved by the creation of a mutually beneficial trade platform within the BRICS. This platform can increase the current level economic, industrial, scientific, technical and cultural cooperation of the participating countries. In addition, such a platform can become a tool for the implementation of the concept of sustainable development in the BRICS countries based on a more flexible and efficient use of available resources and an intensification of the interaction and cooperation between the countries. The current level of cooperation between the BRICS countries can be assessed on the basis of the foreign trade between them. The volumes of the foreign trade between the BRICS countries in 2019 are presented in Table 2. It is important to note that the total exports of the five BRICS countries in 2019 amounted to 3.6 trillion US dollars, which is equal to 19\% of world exports [1]. At the same time, the trade flows between the BRICS countries are unevenly distributed. China is the main trading partner for other BRICS countries. The volume of mutual trade between the other countries is low. Its development is constrained by the lack of bilateral trade agreements. Because of this, the BRICS countries interact with each other within the framework of multilateral agreements. Thus, interaction between Brazil and India is carried out within the framework of the global system of trade preferences between developing countries and the Southern Common Market (MERCOSUR), while China and Russia interact through the Shanghai Cooperation Organization (SCO).

The BRICS countries are characterized by a certain specialization in international trade. For instance, Brazil focuses on the export of mineral fuels and oilseeds; Russia focuses on steel, cast iron, mineral fuels and fertilizers; India focuses on textiles, pharmaceuticals, precious stones and software; China focuses on industrial and electrical goods, textiles, and furniture; South Africa focuses on natural resources, fuel, and precious stones. The differences in the structure of the exports form the basis for the mutually beneficial trade and economic complementarity of the BRICS countries. In 2019, exports to the BRICS countries accounted for 31\% of all Brazilian exports, $16 \%$ of Russian exports, 9\% of India's exports, $7 \%$ of China's exports and 16\% of South Africa's exports. Also in 2019, imports to 
the BRICS countries accounted for $25 \%$ of imports for Brazil, Russia and South Africa, $18 \%$ for India's imports, and 9\% for China's imports. In 2015-2019, the total imports from the BRICS countries to Russia increased by more than $65.0 \%$ [2].

Table 2. Volumes of foreign trade between the BRICS countries in 2019, in billions of US dollars, adapted from [2].

\begin{tabular}{|c|c|c|c|c|c|c|c|}
\hline \multicolumn{8}{|c|}{ Export } \\
\hline To & \multirow{2}{*}{ World } & \multirow{2}{*}{ Brazil } & \multirow{2}{*}{ Russia } & \multirow{2}{*}{ India } & \multirow{2}{*}{ China } & \multirow{2}{*}{$\begin{array}{l}\text { South } \\
\text { Africa }\end{array}$} & \multirow{2}{*}{$\begin{array}{l}\text { Inside the } \\
\text { BRICS, \% }\end{array}$} \\
\hline From & & & & & & & \\
\hline Brazil & 224.0 & - & 1.6 & 2.8 & 62.9 & 1.1 & 31 \\
\hline Russia & 422.8 & 2.5 & - & 7.3 & 56.8 & 0.3 & 16 \\
\hline India & 322.8 & 4.1 & 2.8 & - & 17.0 & 3.9 & 9 \\
\hline China & 2498.6 & 35.5 & 49.5 & 74.9 & - & 16.6 & 7 \\
\hline South Africa & 90.4 & 0.4 & 0.4 & 4.1 & 9.7 & - & 16 \\
\hline \multicolumn{8}{|c|}{ Import } \\
\hline To & \multirow{2}{*}{ World } & \multirow{2}{*}{ Brazil } & \multirow{2}{*}{ Russia } & \multirow{2}{*}{ India } & \multirow{2}{*}{ China } & South & Inside the \\
\hline From & & & & & & Africa & BRICS, \% \\
\hline Brazil & 177.3 & - & 3.7 & 4.3 & 35.3 & 0.8 & 25 \\
\hline Russia & 243.8 & 2.1 & - & 3.9 & 54.1 & 0.8 & 25 \\
\hline India & 480.0 & 3.0 & 6.1 & - & 68.2 & 6.9 & 18 \\
\hline China & 2069.0 & 79.2 & 60.3 & 18.0 & - & 25.9 & 9 \\
\hline South Africa & 88.2 & 1.2 & 0.5 & 4.3 & 16.3 & - & 25 \\
\hline
\end{tabular}

As the above data demonstrate, the development of trade and economic relations between the BRICS countries, taking into account their economic specialization, can be very promising. The intensification of the trade and economic integration is possible with the use of modern digital technologies and tools. One of the most promising areas of integration is the creation of a digital logistics platform that facilitates international operations for all participants. However, until now, there has been a lack of research in this area. Our study is designed to close this gap and provide an analysis of the accumulated experience in the development of digital logistics platforms in the BRICS countries, as well as, based on the analysis, creating an original analytical description of a digital logistics platform in which economic agents of all BRICS countries can operate.

\section{Literature Review}

The development of logistics plays a serious integrating role in the modern economy, expanding the transport capabilities of regions; reducing costs; increasing the speed, safety, quality and efficiency of transport and logistics services; and creating conditions for increasing the added value of produced and transported goods and services, which, ultimately, contributes to the growth of global economic efficiency. The significant influence of logistics on regional development is revealed in numerous studies covering different regions of the world: OECD countries [3,4], the USA [5], China [6-9], and others. However, the integration processes are developing at different rates in different countries and sectors of the economy [10].

The prospects for economic integration processes largely depend on the level of development of the transport and logistics infrastructure. The dynamics of the transport and logistics infrastructure indicators of the BRICS countries from 2000 to 2017 are presented in Table 3. The statistics show that China is the leader in infrastructure development in terms of the given indicators of the length of its railways, highways, and oil and gas pipelines, as well as its freight and passenger traffic. Russia is in second place in terms of the length of its railways and oil and gas pipelines, and its freight and passenger traffic. Brazil is in second place in terms of the length of its highways, followed by Russia. India is in third place in terms of the length of its railways and oil and gas pipelines, and in fourth place in terms of the length of its highways and its passenger traffic. South Africa ranks fifth in the 
length of its railways and oil and gas pipelines. The rest of the indicators are not presented by the statistical services of South Africa.

Table 3. Dynamics of the transport and logistics infrastructure indicators in the BRICS countries from 2000 to 2017, adapted from [11].

\begin{tabular}{|c|c|c|c|c|c|c|c|c|c|c|c|}
\hline & 2000 & 2008 & 2009 & 2010 & 2011 & 2012 & 2013 & 2014 & 2015 & 2016 & 2017 \\
\hline \multicolumn{12}{|c|}{ Length of Railways in Operation (1000 km) } \\
\hline Brazil & 29 & 31 & 30 & 28 & 29 & 29 & 30 & 30 & 30 & 30 & $\mathrm{n} / \mathrm{a}$ \\
\hline Russia & 86 & 86 & 86 & 86 & 86 & 86 & 86 & 86 & 86 & 86 & 86 \\
\hline India & 63 & 63 & 64 & 64 & 64 & 65 & 65 & 66 & 66 & 67 & 67 \\
\hline China & 69 & 80 & 86 & 91 & 93 & 98 & 103 & 112 & 121 & 124 & 127 \\
\hline $\begin{array}{l}\text { South } \\
\text { Africa }\end{array}$ & 21 & 21 & 21 & 21 & $\mathrm{n} / \mathrm{a}$ & $\mathrm{n} / \mathrm{a}$ & $\mathrm{n} / \mathrm{a}$ & $\mathrm{n} / \mathrm{a}$ & $\mathrm{n} / \mathrm{a}$ & $\mathrm{n} / \mathrm{a}$ & $\mathrm{n} / \mathrm{a}$ \\
\hline \multicolumn{12}{|c|}{ Length of Highways $(1000 \mathrm{~km})$} \\
\hline Brazil & 1573 & 1611 & 1557 & 1558 & 1561 & 1561 & 1561 & 1563 & 1571 & 1571 & $\mathrm{n} / \mathrm{a}$ \\
\hline Russia & 532 & 629 & 647 & 665 & 728 & 925 & 985 & 1024 & 1046 & 1054 & 1064 \\
\hline India & 185 & 221 & 229 & 231 & 235 & 241 & 248 & 262 & 265 & 277 & $\mathrm{n} / \mathrm{a}$ \\
\hline China & 1680 & 3730 & 3861 & 4008 & 4106 & 4238 & 4356 & 4464 & 4577 & 4696 & 4774 \\
\hline $\begin{array}{l}\text { South } \\
\text { Africa }\end{array}$ & $\mathrm{n} / \mathrm{a}$ & $\mathrm{n} / \mathrm{a}$ & $\mathrm{n} / \mathrm{a}$ & $\mathrm{n} / \mathrm{a}$ & $\mathrm{n} / \mathrm{a}$ & $\mathrm{n} / \mathrm{a}$ & $\mathrm{n} / \mathrm{a}$ & $\mathrm{n} / \mathrm{a}$ & $\mathrm{n} / \mathrm{a}$ & $\mathrm{n} / \mathrm{a}$ & $\mathrm{n} / \mathrm{a}$ \\
\hline \multicolumn{12}{|c|}{ Length of Petroleum Pipelines (1000 km) } \\
\hline Brazil & $\ldots$ & 7 & 7 & 8 & 8 & 8 & 8 & 8 & 8 & $\mathrm{n} / \mathrm{a}$ & $\mathrm{n} / \mathrm{a}$ \\
\hline Russia & 48 & 49 & 49 & 49 & 51 & 55 & 55 & 55 & 55 & 54 & 53 \\
\hline India & 16 & 26 & 29 & 30 & 31 & 34 & 38 & 41 & 41 & 42 & 44 \\
\hline China & 25 & 58 & 69 & 78 & 83 & 92 & 98 & 106 & 109 & 113 & 120 \\
\hline $\begin{array}{l}\text { South } \\
\text { Africa }\end{array}$ & 3 & 3 & 3 & 3 & $\mathrm{n} / \mathrm{a}$ & $\mathrm{n} / \mathrm{a}$ & $\mathrm{n} / \mathrm{a}$ & $\mathrm{n} / \mathrm{a}$ & $\mathrm{n} / \mathrm{a}$ & $\mathrm{n} / \mathrm{a}$ & $\mathrm{n} / \mathrm{a}$ \\
\hline \multicolumn{12}{|c|}{ Passenger Traffic (All Means) (Billion Passengers-km) } \\
\hline Brazil & $\mathrm{n} / \mathrm{a}$ & $\mathrm{n} / \mathrm{a}$ & $\mathrm{n} / \mathrm{a}$ & $\mathrm{n} / \mathrm{a}$ & $\mathrm{n} / \mathrm{a}$ & $\mathrm{n} / \mathrm{a}$ & $\mathrm{n} / \mathrm{a}$ & $\mathrm{n} / \mathrm{a}$ & $\mathrm{n} / \mathrm{a}$ & $\mathrm{n} / \mathrm{a}$ & $\mathrm{n} / \mathrm{a}$ \\
\hline Russia & 496.2 & 512.2 & 464.2 & 484.0 & 502.8 & 532.6 & 547.2 & 556.2 & 530.0 & 519.8 & 560.6 \\
\hline India & $\mathrm{n} / \mathrm{a}$ & $\mathrm{n} / \mathrm{a}$ & $\mathrm{n} / \mathrm{a}$ & $\mathrm{n} / \mathrm{a}$ & $\mathrm{n} / \mathrm{a}$ & $\mathrm{n} / \mathrm{a}$ & $\mathrm{n} / \mathrm{a}$ & $\mathrm{n} / \mathrm{a}$ & $\mathrm{n} / \mathrm{a}$ & $\mathrm{n} / \mathrm{a}$ & $\mathrm{n} / \mathrm{a}$ \\
\hline China & 1226 & 2320 & 2483 & 2789 & 3098 & 3338 & 2757 & 2865 & 3006 & 3126 & $\mathrm{n} / \mathrm{a}$ \\
\hline $\begin{array}{l}\text { South } \\
\text { Africa }\end{array}$ & $\mathrm{n} / \mathrm{a}$ & $\mathrm{n} / \mathrm{a}$ & $\mathrm{n} / \mathrm{a}$ & $\mathrm{n} / \mathrm{a}$ & $\mathrm{n} / \mathrm{a}$ & $\mathrm{n} / \mathrm{a}$ & $\mathrm{n} / \mathrm{a}$ & $\mathrm{n} / \mathrm{a}$ & $\mathrm{n} / \mathrm{a}$ & $\mathrm{n} / \mathrm{a}$ & $\mathrm{n} / \mathrm{a}$ \\
\hline \multicolumn{12}{|c|}{ Freight Traffic (All Means) (Billion Tons-km) } \\
\hline Brazil & $\mathrm{n} / \mathrm{a}$ & $\mathrm{n} / \mathrm{a}$ & $\mathrm{n} / \mathrm{a}$ & $\mathrm{n} / \mathrm{a}$ & $\mathrm{n} / \mathrm{a}$ & $\mathrm{n} / \mathrm{a}$ & $\mathrm{n} / \mathrm{a}$ & $\mathrm{n} / \mathrm{a}$ & $\mathrm{n} / \mathrm{a}$ & $\mathrm{n} / \mathrm{a}$ & $\mathrm{n} / \mathrm{a}$ \\
\hline Russia & 3638 & 4948 & 4446 & 4752 & 4915 & 5056 & 5084 & 5080 & 5108 & 5198 & 5479 \\
\hline India & $\mathrm{n} / \mathrm{a}$ & $\mathrm{n} / \mathrm{a}$ & $\mathrm{n} / \mathrm{a}$ & $\mathrm{n} / \mathrm{a}$ & $\mathrm{n} / \mathrm{a}$ & $\mathrm{n} / \mathrm{a}$ & $\mathrm{n} / \mathrm{a}$ & $\mathrm{n} / \mathrm{a}$ & $\mathrm{n} / \mathrm{a}$ & $\mathrm{n} / \mathrm{a}$ & $\mathrm{n} / \mathrm{a}$ \\
\hline China & 4432 & 11,030 & 12,213 & 14,184 & 15,932 & 17,380 & 16,801 & 18,167 & 17,836 & 18,663 & 19,737 \\
\hline $\begin{array}{l}\text { South } \\
\text { Africa }\end{array}$ & $\mathrm{n} / \mathrm{a}$ & $\mathrm{n} / \mathrm{a}$ & $\mathrm{n} / \mathrm{a}$ & $\mathrm{n} / \mathrm{a}$ & $\mathrm{n} / \mathrm{a}$ & $\mathrm{n} / \mathrm{a}$ & $\mathrm{n} / \mathrm{a}$ & $\mathrm{n} / \mathrm{a}$ & $\mathrm{n} / \mathrm{a}$ & $\mathrm{n} / \mathrm{a}$ & $\mathrm{n} / \mathrm{a}$ \\
\hline \multicolumn{12}{|c|}{ Passenger Traffic by Air (Million Persons-km) } \\
\hline Brazil & 48,165 & 69,080 & 76,385 & 93,991 & 107,816 & 113,488 & 116,032 & 122,475 & 127,528 & 122,076 & 128,940 \\
\hline Russia & 53,410 & 122,601 & 112,469 & 147,119 & 166,760 & 195,775 & 225,157 & 241,429 & 226,849 & 215,594 & 259,385 \\
\hline India & 26,212 & 78,445 & 89,443 & 103,171 & 112,794 & 105,208 & 114,036 & 126,903 & 145,787 & 170,085 & $\mathrm{n} / \mathrm{a}$ \\
\hline China & 97,054 & 288,280 & 337,524 & 403,900 & 453,696 & 502,574 & 565,676 & 633,419 & 728,255 & 837,813 & 951,304 \\
\hline $\begin{array}{l}\text { South } \\
\text { Africa }\end{array}$ & $\mathrm{n} / \mathrm{a}$ & $\mathrm{n} / \mathrm{a}$ & $\mathrm{n} / \mathrm{a}$ & $\mathrm{n} / \mathrm{a}$ & $\mathrm{n} / \mathrm{a}$ & $\mathrm{n} / \mathrm{a}$ & $\mathrm{n} / \mathrm{a}$ & $\mathrm{n} / \mathrm{a}$ & $\mathrm{n} / \mathrm{a}$ & $\mathrm{n} / \mathrm{a}$ & $\mathrm{n} / \mathrm{a}$ \\
\hline
\end{tabular}

Various aspects of logistics integration are considered in works devoted to the combination of logistics functions [12], the principles of material flow management [13], the efficiency of enterprises [14,15], the stages of integration [16], the outsourcing of logistics functions [17], supply chain coordination [18], operational functions [19], the improvement of customer satisfaction through logistics [20], cross-functional integration [21], logistic coordination [22], systems integration [23], and logistic integration [24].

The approaches to the definition of logistics platforms are currently different. Sometimes a logistics platform is defined as a homogeneous part of the supply chain, centrally managed by a focal company [25]. The article [26] clarifies the understanding of the logistics platform. It is defined as part of a logistics system, centrally managed by the focus company, and includes logistics operations, physical infrastructure and processes, 
and an information system. A logistics platform is sometimes described as a strategic interface between regional and global logistics networks, integrating various supply chain agents to improve logistics performance [27]. Furthermore, a logistics platform is understood as a specialized territory providing services and infrastructure for joint intermodal transportation, increasing the consumer value of transported goods [28]. Vancza, Egri, and Karnok [29] described a logistics platform as a service for the provision of integrated information and communications services that affect supply chain operations. Russian authors often describe a logistics platform as a specific organizational structure. For example, a logistics platform is defined as a structure that forms a common information space for all of the participants in supply chains, including information on the results of their activities, competencies and technological operations [30]. Karnaukhov described a logistics platform as a special organizational structure that coordinates the processes of goods movement and forms of interaction between participants in supply chains in order to achieve their common strategic and tactical goals while minimizing material, labor and financial costs [31]. Finally, Dunaev and Nesterova proposed a definition of a translogistic platform as an economic space for network interaction between companies participating in integrated supply chains, united by a common process of generating added value and a single technology for the managing of a business network [32].

Many authors note the important role of digital innovations in increasing the efficiency of various logistics processes, from warehousing and transportation [33-35] to general logistics and trade platform solutions [36-38]. The DLPs on the blockchain basis can help prove quality and provenance, and combat fraud [39]. Auditable supply chains with real- or near-real-time data can also make it easier to trace faulty materials, ingredients or products to their source, increasing the timeliness and accuracy of recalls and other public safety measures [40]. The DLPs can also help streamline compliance procedures, manage complexity, and improve supply chain coordination [41].

The digital transformation of modern business has a serious impact on the field of transport and logistics services, and supply chain management. The development of transport and logistics services based on integrated digital platforms and the use of digital logistics tools increases the reliability and stability of supply chains, and reduces the delivery time of goods. The information that is available to all interested parties makes it possible to predict the development of solutions to potential problems in the operation of transport and logistics systems, and to obtain a significant economic effect in the industry as a whole.

We believe that the common BRICS DLP will serve the development of trade and economic relations between the BRICS countries, as well as the creation of safe, balanced and dynamic transnational transport and logistics systems. The efficient functioning of the transport system is the key to international trade and integration into global value chains. Communication infrastructure, information and telecommunication technologies, as a key tool of the logistics system, will help accelerate growth and reduce costs. Thus, the digital logistics platform will become an important factor in the economic growth and international cooperation of the BRICS countries.

Blockchain technology could become the key technology for the building of a common digital logistics platform for BRICS countries. By now, blockchain has proven itself to be a revolutionary tool in the global economy and trade $[42,43]$. It is widely used not only in the financial sector, but also in other economic sectors, including logistics and supply chain management [44-46]. In addition, it can improve the resilience of the supply chain [47-49]. In this regard, our proposed analytical description of the BRICS common digital logistics platform will be based on blockchain technology.

\section{Methodology}

Nowadays, logistics networks are becoming more customer-centric, and are seeking to adapt to the rapidly changing needs of customers for the transport, distribution and delivery of personalized goods. The creation of digital platforms is a kind of ecosystem of 
new advanced digital technologies that unite geographically distributed participants in the design and production processes, and increase the level of flexibility and customization, taking into account the requirements of consumers based on predictive analytics and big data. Digital logistics platforms are one of the tools for organizing and managing interrelated flows of material and financial resources. We propose to define a digital logistics platform as a set of technological and modeling tools for material and financial flows, ensuring their system integration based on digital technologies. The knowledge fields used to develop the DLPs' analytical description can include both basic theories (economic theory, logistics and supply chain management, financial theory) and special fields that include the science of socio-economic systems planning, organization and management, etc. [50].

The research methodology includes methods for statistical data analysis, a case study of DLP development in the BRICS countries, an analysis of the existing definitions and methods for developing DLP, and methods of systemic analysis. This paper analyzes the level of development of international trade, the state of the logistics infrastructure and the experience of the BRICS countries in the development and use of digital logistics platforms. For this analysis, we used statistical data from the analytical reports of the BRICS, the international interactive database Trade Map, reports of the statistical services of the BRICS countries, and the World Bank Logistics Performance Index (LPI), etc. In order to analyze the existing definitions and methods of the DLPs, we used the most cited articles in this field from the Scopus and WoS databases. Based on the results of this analysis, taking into account the existing approaches of DLP development, we designed the methodological approach to the common BRICS DLP design using systemic analysis methods.

\section{Analysis and Results}

\subsection{Comparison of the Levels of Logistics Development in the BRICS Countries Based on the LPI Index}

The level of logistics development in the BRICS countries varies greatly. It can be assessed on the basis of the LPI, as calculated every two years by the World Bank. This index includes an assessment of the country's trade and transport infrastructure quality, the speed and efficiency of customs clearance, the quality and cost of organizing international transport, logistics services, the ability to track the movement of goods, and the timeliness of deliveries. The LPI is calculated based on data from international, national or regional logistics and warehouse operators. The assessment of the efficiency of the logistics was carried out on a scale from 1 (minimum) to 5 (maximum) points based on expert assessments. Consider the positions of the BRICS countries in the international LPI ranking (Table 4).

Table 4. Rating of the BRICS countries in the LPI 2018 ranking, adapted from [51].

\begin{tabular}{ccccccccc}
\hline Country & LPI Rank & LPI Score & Customs & Infrastructure & $\begin{array}{c}\text { International } \\
\text { Shipments }\end{array}$ & $\begin{array}{c}\text { Logistics } \\
\text { Competence }\end{array}$ & $\begin{array}{c}\text { Tracking/ } \\
\text { Tracing }\end{array}$ & $\begin{array}{c}\text { Timeliness } \\
\text { China }\end{array}$ \\
\hline South & 33 & 3.61 & 3.29 & 3.75 & 3.54 & 3.59 & 3.65 & 3.84 \\
Africa & 3.38 & 3.17 & 3.19 & 3.51 & 3.19 & 3.41 & 3.74 \\
India & 44 & 3.18 & 2.6 & 2.91 & 3.21 & 3.13 & 3.32 \\
Brazil & 56 & 2.99 & 2.41 & 2.93 & 2.88 & 3.09 & 3.11 \\
Russia & 75 & 2.76 & 2.42 & 2.78 & 2.64 & 2.75 & 2.65 \\
\hline
\end{tabular}

As can be seen in Table 4, China is in first place in terms of logistics development in accordance with the general LPI indicator among the BRICS countries (26th position in the overall rating of countries), followed by South Africa (33rd), then India (44th), Brazil (56th) and, finally, Russia (75th). At the same time, China is the leader in all of the individual indicators. South Africa is also always in second position after China in all of the individual indicators. India is ranked third in four indicators: customs, international shipments, logistics competence and tracking/tracing. At the same time, in 
terms of logistics infrastructure and the timeliness of deliveries, India is behind Brazil's third position. Russia is in last place among the BRICS countries in terms of the general LPI indicator, as well as in five individual indicators: infrastructure, international shipments, logistics competence, tracking/tracing and delivery timeliness. However, according to the customs indicator, Russia is ahead of Brazil, and comes to the fourth position in the ranking of the BRICS countries.

At the same time, it should be noted that despite Russia's lower positions in the LPI rating compared to other BRICS countries, it significantly improved its position in 2018 compared to 2016. As such, in 2016, Russia occupied only the 99th place in the rating, with a score of 2.57, while in 2018 it immediately rose by 24 points and received 75 th place, These dynamics indicate a significant improvement in the logistics industry in Russia. This improvement is associated with progress in the customs clearance of goods (2.42 in 2018 versus 2.01 in 2016), logistics infrastructure (2.78 in 2018 versus 2.43 in 2016), international shipments (2.64 in 2018 versus 2.45 in 2016) and timeliness (3.31 in 2018 versus 3.15 in 2016). At the same time, the cargo tracking/tracing indicator in Russia increased slightly (2.65 in 2018 versus 2.62 in 2016), and the indicator of logistics competence even decreased slightly (2.75 in 2018 vs. 2.76 in 2016).

Thus, the analysis shows significant differences in the level of logistics development among the BRICS countries. China and South Africa have a fairly high performance in the LPI index, India and Brazil occupy the middle positions, and Russia is behind other BRICS countries. However, it should be noted that, in recent years, Russia has been actively developing its logistics and improving its position in the ranking. At the same time, it is obvious that the described differences between the BRICS countries in terms of the level of logistics development will seriously affect the use of modern information technologies in this industry. It is logical to assume that the processes of digitalization and DLP evolution will develop more rapidly in countries with higher positions in the LPI rating.

\subsection{Chinese Digital Logistics Platform, Logink}

Let's start our analysis with China, as the most developed country in terms of logistics. China was the first among the BRICS countries to start creating a national digital logistics platform, called Logink. The development of the platform took seven years. Logink was launched in 2012, and has grown into a platform with 400,000 members and 20 million messages per day. The turnover at this DLP exceeds 1.35 trillion USD. Among the enterprises participating in the DLP, 28\% are engaged in production, $17 \%$ in trade, and 55\% in transportation and warehousing [52].

The logistics industry in China is developing at a fast pace, as shown by the LPI. However, this development is, to a certain extent, restrained by the information technology capabilities and methods of standardizing information in the logistics industry. Furthermore, there is an important problem of information asymmetry arising between manufacturers, buyers, and transport and logistics companies. These factors have created an urgent need for a unified, efficient and secure public platform for the logistics information exchange between market players and regulators. Building such a unified digital platform has become a global goal for China. Logink contributes to logistics cooperation efficiency, as well as to the improvement of logistics processes' organization at the enterprise level.

Logink provides three basic services:

- $\quad$ Service of standards: Logink includes a system of standards for information organization and exchange in the field of transport and logistics, and provides unified standards for data exchange for participants in supply chains.

- Information exchange service: Logink creates a digital analogue of the "high-speed highway" for the logistics information exchange between market participants.

- Data service: Logink offers access to regulatory documents and databases (profiles of market participants, logistics parks, airports, ports and railways, tracking, resource 
provision, government sector regulation policy) through a single information window for logistics services.

Logink currently integrates the transport and logistics systems of China, Korea and Japan. Thus, Logink ensures reliability, safety, efficiency and uninterrupted information exchange between national logistics platforms and international logistics information systems. It aims to unify logistics data standards between logistics platforms of partner industries, and to provide transparent public logistics information across all of the supply chains. Logink includes dozens of regional exchange hubs and five industry logistics hubs, including aviation, road, water, rail and postal hubs [53].

Logink has now completed the standardization of more than 50 logistics management programs covering $70 \%$ of the major enterprise systems in China, shortening the interaction cycle among them from 8 months to 1 week, and accelerating the progress in information standardization by about 3 years. Thus, Logink stimulates the interconnection of production, trade and transport participants in the supply chain, creates synergies, increases efficiency and reduces logistics costs. More than 50 large enterprises-such as Xinhua Bookstore and COSCO Logistics — thanks to Logink, have formed effective relationships with the logistics systems of associated companies. Huadong Medicine Company Limited joined Logink to improve its logistics efficiency by $80 \%$, cut logistics information processing time by $95 \%$, and optimize its logistics cycle by 3\%. Logink currently offers over 10 products, such as: cooperation in the supply chain, cross-border e-commerce, logistic resources, the factoring of freight, booking containers, and the payment of trade fees, etc. [53].

Currently, Logink is actively developing cooperation in the exchange of logistics ties with ASEAN and the EU in order to provide information support for global logistics. China is confident that Russia lacks a platform among the partner countries. However, despite lengthy negotiations (more than 7 years), Russia has not yet made a decision to join Logink. Perhaps this is due to the fact that, for Russia, it is more urgent to create its own logistics platform focused on the Eurasian Economic Union (EAEU).

\subsection{Digital Logistics Platforms in Brazil}

The formation of a digital logistics platform in Brazil is now in its infancy. At the moment, there is only one company that is developing such a digital platform for Brazil. This is Singapore's Global Logistic Properties (GLP). The company is present in 36 markets in various Asian countries. The company has teamed up with three large investment funds to buy logistics assets from the Brazilian company Prosperitas for $\$ 1.45$ billion. At the moment, the head of the company has announced plans to create a logistics platform in Brazil. Thus, when exactly the digital platform for Brazilian logistics will be organized remains unknown [54].

However, there are already companies in Brazil that have not yet reached the digital platform level, but are performing significant digital services in the logistics sector. An example is CargoX. CargoX is an international company that calls itself an "international transport exchange", which appeared as a startup just a few years ago. The company specializes in digital solutions in the field of logistics, transportation and workflow based on a blockchain platform. It is often referred to as the Brazilian "Uber" for international travel. There are currently over 20,000 companies represented on its platform, collectively bringing together over 400,000 truck drivers [55].

Today, CargoX is building a network of partnerships with leading regional and global manufacturers and service providers, and actively participates in the formation of standards to ensure interaction between players in the industry. The main CargoX focus is on creating user benefits, ensuring transparent logistics processes, and improving the user interface. CargoX is not a competitor to transport and logistics companies, as it helps to connect the participants in the supply chain. Companies using the CargoX platform solution gain clear competitive advantages and increase profitability. Thus, this project can be considered a digital platform, but with a narrow range of services. 
In addition, the Twill digital logistics platform, developed by the Danish shipping company Maersk, is now operating in Brazil. Twill began operations in Brazil on 20 March 2019, in order to simplify logistics and provide companies with global benefits for local businesses. The platform provides Brazilian companies with greater control over shipments, quotas and orders, and cargo tracking services with simplified workflow schemes. According to the Twill CEO, the platform offers "fantastic trading opportunities in Brazil and beyond for small and medium-sized businesses." Taking into account the fact that small and medium-sized businesses in Brazil employ more than 56 million people and account for $20 \%$ of the GDP, it can be concluded that the project is highly important for the development of the country [56].

Thus, the DLPs in Brazil today include three components that are at different stages of development:

1. The national Brazilian GLP platform with the declared full functionality is currently under development.

2. The Brazilian startup CargoX is fully launched, but provides users with limited DLP functionality, focusing on electronic document management and online tracking.

3. The Danish logistics DLP, Twill, developed by the logistics company Maersk, acts as a full DLP. However, since it was developed by a Danish company, it is not correct to use it as an indicator of the DLPs' development in Brazil.

\subsection{Digital Logistics Platforms in Russia}

As was shown earlier, Russia lags slightly behind other BRICS countries in its level of logistics development. This lag can be traced to the digital logistics platform's development. At the moment, the Russian analogue of the DLP is under development. It is being carried out by the Digital Transport and Logistics Association. The Association brings together the leaders of the Russian market in all types of transport. Today, the members of the association are the Russian Railways, Glosav, Aeroflot, ZashchitaInfoTrans, RTInvest Transport Systems, the State Corporation for Air Traffic Management, Digital Radio Engineering Systems, TransTelecom, and Azimut. The Association members control about $70 \%$ of the Russian transport market [57].

The idea of the Russian DLP is to combine key services for transport and logistics in Russia. The result of this development should be a single digital environment, including an array of data, which can be accessed by all of the market participants. The participants will be able to enter their information into the DLP, as well as developing their services and applications based on its data. These services can be both public and private. One of the government services, for example, could be digital maps of transport infrastructure indicating additional data (such as permissible loads on a railway tracks or bridges, a list of stops and rest places, etc.). In addition, it is assumed that the DLP will unite the digital systems of the participants for the information support of transport and logistics processes. At the moment, the Association "Digital Transport and Logistics" is developing common standards for data management in the logistics industry, and is creating a full-fledged DLP.

The implementation of the DLP will contribute to the development of multimodal freight transport, ensure high functionality and transport security, allow the implementation of the greening of transport and logistics processes, create a basis for the development of unmanned vehicles, and form effective digital tools for the monitoring, coordination, management and control of transport infrastructure at the national level. It is expected that the use of the DLP will create a trusted environment for intra-industry communication; will offer clear, transparent and controlled conditions for the transportation of any cargo; will reduce delivery times by increasing the speed of information exchange; and will automate administrative procedures, ensuring the electronic document flow. The creation of the DLP should make Russia an attractive partner for all of the countries of Eurasia, and should promote the development of a transit zone between Europe and Asia.

A feature of the DLP, which is being created by Russian developers, will be the implementation, first of all, of interaction between businesses and the government. This 
is a certain limitation of the platform, as with such a typical Russian focus on interaction in the B2G (business to government) sector, a situation may arise in which small and medium-sized businesses will not receive adequate support in terms of the organisation of logistics processes.

\subsection{Digital Logistics Platforms in India}

In 2016, the iFreightBox DLP project was launched in India. This project brings together logistics service providers, shippers, consignees, warehouses and terminals, carriers, drivers and other stakeholders, and makes the management of freight transport simple, fast and safe. The iFreightBox can be considered a digital logistics platform, but it is worth noting that, in some respects, it is inferior to DLPs developed as part of digital industrywide solutions based on machine learning technologies [24]. The iFreightBox is targeted at the B2B sector, and it provides features such as: a system of customer relationship management, an RFID system, order management, supplier management, transportation management, human resources management, a satellite navigation system, incident reporting, a maintenance service, routing, invoicing, shipment management, and load optimization [58].

The iFreightBox functionality shows that the Indian DLP is quite developed. It should also be noted that the developers offer a special smartphone app to increase the DLP's accessibility, convenience and online tracking services.

\subsection{Digital Logistics Platforms in South Africa}

The situation in South Africa can be considered the most controversial from a digital innovation point-of-view. At the moment, the South African Republic does not have its own development of a DLP. Nevertheless, there is a platform in the South African territory that allows the enterprises of the country's logistics industry to stay afloat in the context of digital transformations. It is the Saloodo project, which DHL launched in Germany in 2017. It allows manufacturers and suppliers to connect with carriers and forwarders through the online platform. The service covers booking, freight shipping, documentation and payment. These are the basic business processes that the German platform allows businesses to automate in the rapidly developing logistics industry.

According to the DHL, Saloodo is the first digital platform available in South Africa. It offers cost optimization, routing, cargo delivery and transit for shippers and transport service providers. Furthermore, the subsidiary DHL company Saloodo reserves the goal of developing in other African countries [59].

Thus, the BRICS countries can be ranked in accordance with their level of digital logistics platform development:

1. China is the leader among the BRICS countries in the field of logistics and the developer of the world's most powerful digital logistics platform.

2. India ranks second, because in comparison with other BRICS countries, in addition to China, it has the most developed nationally developed DLP.

3. Brazil is the third in the ranked list in terms of DLP development, as the existing DLP is much inferior to other platforms in terms of functionality.

4. Russia currently neither cooperates with other countries nor works on foreign platforms, and its own DLP is currently under development. Nevertheless, the Ministry of Transport of the Russian Federation reported that the Russian digital logistics platform will be launched in 2024, uniting all of the regions of the country [60].

5. South Africa does not have its own DLP, but currently uses German DLP services.

Given the above-mentioned leadership of China in logistics and digital infrastructure development, it would seem that it would be possible to use its platform for interaction with other BRICS partners. However, it is obvious that China's dominance, not only in trade but also in technology, can negatively affect economic sovereignty, technological development and political stability in other BRICS countries. In this regard, other BRICS members are currently refusing to join China's digital logistics platform, and are seeking 
to develop their own platforms. The solution to this dilemma could be the creation of a general digital platform for the trade and logistics cooperation of the BRICS countries on an equal, fair and safe basis for all of the participating countries.

4.7. International Digital Logistics Platforms as a Tool for the Development of Trade and Economic Relations between the BRICS Countries

As shown above, the BRICS countries recognize the importance of the logistics component of economic development, and are involved in the development of digital logistics platforms, although at different speeds. The inequality in the level of the logistics infrastructure and DLP development in the BRICS countries revealed in Sections 4.1-4.6 can be overcome on the basis of the DLP proposed in Section 4.7 and Section 4.8. A general digital platform of the BRICS, on which all of the participating countries will have equal representation, can become not only a tool for the intensification of BRICS trade and economic ties but also means the equalization of their economic development. The review and analysis of the BRICS countries allows us to talk about broad prospects for international cooperation in the creation of logistics platforms based on the digitalization of transport corridors under the control of scientifically based algorithms. There is a problem related to the development of algorithms for the application of innovative technologies in order to increase the efficiency of the BRICS countries' transport and logistics systems. In order to increase the efficiency of trade and the economic interaction between the BRICS countries, it is necessary to optimize the interaction between sea, rail and air carriers, as well as to take into account the processes at the nodes of the logistics network, such as distribution centers, transshipment ports and railway warehouses. At the same time, transport efficiency is associated with the flows of information exchange about the properties and parameters of the goods, route destinations and throughput, resources of equipment, and the mobile fleet of freight carriers.

The widespread use of digital technologies in the concept of Machine-to-Machine (M2M) interaction, and in particular, the development and standardization of machinereadable codes with corrective properties, make it possible to move to end-to-end automation of the most important segment of multimodal transportation in the 3PL (Third Party Logistics) concept (3PL means an organization's use of third-party businesses to outsource elements of its distribution, warehousing, and fulfillment services). We propose the formation of control algorithms for DLP based on the combination of modern cross-docking, pick-by-line technologies and methods of mathematical programming in conditions of environment uncertainty. This approach is based on the analysis of world experience in the use of digital tracking which demonstrates that the main effect during implementation is achieved precisely due to the capabilities of formalized algorithms based on the theory of process optimization. Due to the fact that up to $90 \%$ of the volume of raw material and finished product flows distributed both in the BRICS countries and in the world is carried out in a multimodal type, the implementation of the proposed approaches will give not only economic but also social and environmental effects.

The ongoing process of the widespread use of intelligent automation tools such as laser and RFID scanners, robotic warehouse complexes, and autonomous transport in the BRICS countries and in the world is based on the use of machine-readable codes. As such, to solve the identification problem, it is possible to use the entire arsenal of tools, ranging from linear barcode to two-dimensional QR (Quick Response) codes for recognition tools based on RFID tags. The expediency of using these means is primarily based on the conditions of finding the item during the entire track, as well as restrictions on the equipment used during transportation. The modern level of M2M interactions is organized using cloud-based Internet solutions; therefore, in logistics algorithms, both the individual SKU (Stock Keeping Unit) of goods and large quantities of them formed into packages are meant as a control object. In this case, combined schemes are used based on RFID-tags containing the addresses of individual units and requiring a call to the forwarding server. Such identification makes it possible to switch to M2M algorithms when carrying out 
cross-docking procedures and pick-by-line selection, which are present in the vast majority of the logistics schemes of the BRICS countries.

Due to the flexibility of M2M technologies and alternative modes of transport, as well as the expansion of functionality, higher levels of services, such as 4PL and 5PL (the 4PL, or fourth-party logistics provider, in addition to the 3PL functions, deals with management logistics; 5PL, or fifth-party logistics providers, in addition to $4 \mathrm{PL}$, provides network business services and runs all of the aspects of the supply chain), have been formed in the world, and first of all in China, as the most technologically advanced BRICS participant. Such forms are more common in other segments of the economy of the BRICS countries, for example, in P2P (Peer-to-Peer or Partner-to-Partner) networks, online auctions and global trading platforms, etc. In this paper, they can be considered as a prospect for the application of the results.

\subsection{Analytical Description of a Digital Logistics Platform Proposed for BRICS}

The traditional representation of the supply chain is linear, with a discrete sequence of design, planning, manufacturing and delivery. However, today, logistics is increasingly shifting to the use of digital supply networks, characterized by the increasing potential of a network of partners in the logistics ecosystem. Digital supply chains operate on information from multiple sources, and improve the efficiency of physical production and distribution processes. The networked representation of an intelligent digital supply chain is focused on increasing the resilience to potential external influences.

The interconnected grid of the new digital supply chain model has a digital core at the center, and provides interoperability between all of the elements of the network. Communication in this model is multidirectional. The model assumes the emergence of connections between traditionally unrelated elements, and takes into account the immanence of innovation throughout the entire life cycle of the digital supply chain. The scientific novelty of our approach lies in the substantiation of the concept of the formation of supply chains, which makes it possible to introduce the digital core of economic relations as a new economic category related with the concept of a digital grid of interconnected processes in supply chains. As a conceptual basis for the building of the BRICS DLP, we propose to use an approach focused on the use of a distributed network of elements combined into a particular ecosystem that provides an automated, reliable and efficient logistics service. The main idea of the approach is to provide access to all of the participants in the supply chain. An important condition for the platform is a sufficient number of users. Only in this case can the platform can be truly functional.

The concept of a logistics ecosystem built in the form of distributed ledgers and offering an approach to solving the problem of the complexity of modern supply chains by dividing them into smaller, functionally independent parts can be represented as a modular platform. This will allow users to expand the functionality of existing platform elements, or to add their own as needed. The ability to modify existing and add new elements will gradually give the platform an optimal shape in accordance with the needs of users. It is important to note that the proposed platform combines blockchain and IoT technologies in a new and innovative way. The interaction between the elements of the platform is built on the basis of the IoT, which serves as a bridge between the real and virtual worlds. Blockchain is used as a means of registering agreements, concluding transactions, monitoring processes, and providing public access to information. It ensures the reliability of supply chains by connecting platform elements into a secure and public system.

The proposed modular digital logistics platform can include various types of elements; however, in order to ensure its operability, the following seven are required: portal, service, user, interface, contract, architecture, and rating. Let's describe them in more detail.

The first element of the platform, which serves as an entrance for new users and provides them with all of the necessary information about the platform, is the portal. It also contains a list of all of the elements of the platform, the rules for their operation and 
interaction with each other, and algorithms for their searching. The portal element can be developed as a blockchain-based smart contract.

The second element of the platform is the service. It is intended to serve the subjects of the platform. This element connects the physical and virtual supply chains. The main component of the service element is the API (Application Programming Interface), which supports communications between platform subjects via the Internet. Transport, warehousing, and insurance services, etc., are examples of service items. The task of the platform development is the automation of the entire logistics services process on the platform.

The third element is the user. This element is generated for each user accessing the platform; for example, it can be a manufacturing enterprise that needs to send finished products to a customer. The user element must consist of two blocks: the first is a physical package, and the second is its virtual copy. It is proposed to equip the physical package with an IoT device that provides communication with a virtual copy and allows the monitoring of the parameters of the transportation of a physical package, from the route of movement to the temperature and other conditions which are important for a particular cargo. In this case, all of the management processes and the computations necessary for them are performed outside the physical package on external resources (servers, clouds, etc.). As such, smart cargo packaging uses only the necessary amount of electronics. Consequently, it will be cheaper, and service processes will be more economically efficient.

The fourth element is the interface. The main purpose of this element is to provide users with access to all of the elements and functions of the platform. The front-end node implementation can be built as a decentralized web page based on peer-to-peer technology.

The fifth element is the contract. This element is responsible for fixing agreements between the user and service elements of the platform. Its work is built on the basis of smart contracts. All of the contracts concluded on the platform are fixed using blockchain. At the same time, their content is encrypted, if necessary, to ensure confidentiality. At the conclusion of the contract, part of the amount is blocked on the accounts of each of the participants. In case of the violation of the terms of the contract, the blocked amount is transferred to the injured party to compensate for losses according to predetermined rules. If the contract is fulfilled in good faith by all of the participants, the blocked amounts are returned to the original owners, and the platform ensures settlements between them.

The sixth element is architecture. This element provides communication between all of the parts and elements of the platform. It can be implemented in different ways; for example, it can connect only the address and element type, or it can use complex connections (for example, API). Its implementation can also be built on the basis of a smart contract. In order to provide communication and the exchange of messages between elements of the platform, appropriate detection mechanisms are needed. For example, the Address Resolver (ARN) mechanism can be used to map items to their IP addresses. ARN is similar to DNS, which maps domain names to IP addresses. ARN can be implemented as a smart contract. ARN contains the address information for all of the platform elements. Therefore, users can interact with each other and manage their supply chains.

The seventh element is the rating. This element allows the system to calculate the rating of each user of the platform, evaluating his or her actions. The functionality of the platform assumes the exclusion of bad actors based on the generated rating. The objective rating is calculated on the basis of reliable data from the platform elements, especially the contract element, which fixes the violation of the terms of the contract by the entities. Users with high ratings must receive positive reinforcement to ensure the reliability and efficiency of the platform.

Consider the process of providing services by a digital platform using the example of the production of a particular product. The first stage is the search for a platform: the company is faced with the problems of managing its supply chain. It needs automated processes to optimize its production, transport and logistics activities. It finds the platform through the interface element because the portal element uses it to represent platform 
information. The second stage is to study the platform. The portal provides a link to all of the other elements of the platform. If a company is looking for a product transport service, their focus is on the architectural element that matches transport providers with their APIs. The third stage is using the platform. The company receives a list of all of the suppliers on the platform and sends them its requirements using the suppliers' API. Transport service providers form their proposals. The company chooses the optimal one and concludes an agreement with the selected supplier. The agreement is recorded in the contract element in the form of a smart contract, which the company and the transport provider sign with digital signatures. In accordance with the terms of the agreement, both parties fix a certain amount for penal fines in the case of the non-performance or bad performance of the contract.

After the contract is executed, the parties report the results of the interaction. If both parties confirm the proper execution of the contract, the funds are distributed between them in accordance with the fixed conditions. If one of the parties does not confirm the performance of the contract, the funds are blocked until the dispute is resolved. In this case, the rating element takes into account the reliability of the users based on the results of the contract execution. The fourth stage is interaction modification. If a company wants more reliability and traceability of supplies, it can use smart packaging. Each package sent in smart packaging can use its own user element and interact with other platform elements. Smart packaging is programmed according to the criteria set by the company. For example, if a company prefers to transport the product in the most economical way, then the platform will look for the cheapest offers from service providers. If special temperature (or humidity) conditions are required to ensure product quality, the product must be loaded into a vehicle that meets these conditions. The new smart contract will add to the terms of the agreement a function that obliges the transport company to provide certificates that its vehicles can provide the required conditions during transportation.

\section{Discussion}

The results of our study show, on the one hand, the high degree of unevenness in the development of transport and logistics infrastructure in the BRICS countries, and the Chinese dominance. On the other hand, we have identified a significant potential for the economic relations development in the member countries of the group. Our analysis of the BRICS countries demonstrates the high importance of the infrastructure projects implementation in the transport and logistics sector for economic growth and social development, which is consistent with the previously obtained results $[4,5,8,9]$. At the same time, the strengthening of the economic integration among the BRICS countries will help to overcome the problem of the inequality in their development.

It is important to note that, like a number of previous authors who studied the impact of technological trends on the economy [26-28], we came to the conclusion that the use of digital technologies is promising for logistics and trade development. In addition, our research has confirmed the promise of the use of blockchain as a tool for the creation of international digital logistics platforms, ensuring the transparency and reliability of supply chains, the ease of monitoring and control, and the promotion of sustainable development [38-41]. Thus, our study supports the previously obtained scientific results and expands them in the context of the creation of the original analytical description of the BRICS DLP.

The proposed conceptual scheme for the management of material and information flows within the BRICS logistics ecosystem takes into account digital transformation, and makes it possible to implement a distinctive feature of the modern stage of development of logistic interaction: the fundamental difference between the movement of material flows with a significant length of time and online information interaction, including the exchange of financial flows [61,62]. This approach provides a new opportunity for using not only the mathematical modeling of the activity of network logistics interaction but also for the development of complex, previously inaccessible algorithms that form the basis of 
software and hardware for the management of digital logistics networks [63]. The technical feasibility of the practical implementation of software and hardware systems is based on the available mass supply of hardware for M2M interaction and the standardization of digital data exchange protocols and machine-readable encodings. This provides a stable data exchange interface between the digital logistics platform, the producer (the source of the material flow in the network) and the consumer.

The implementation of the developed method for the construction of the information structure of digital logistics platforms has another important advantage. It allows us to build processes using the most advanced methods of optimization theory, and is consistent with the current tasks of logistics. At the same time, integrated economic indicators serve as the optimization criterion. This concept fully reveals the benefits of advanced planning. The development and study of the proposed structure of the digital logistics system was carried out as a universal scalable system, indifferent to the nature of the material flows being moved. This is especially important for the BRICS, because in addition to discrete cargoes (containers, packages, individual cargo units), the segment of continuous cargoes, primarily energy products, is also significant.

The interactions among each element of the network in a digital logistics platform can be interpreted as the manifestation of a new paradigm for the description of the model of digital processes in logistics networks. Scientific research in the field of the development of a model of digital logistics processes is supported by the postulates of basic and special branches of knowledge, which cover such sections of economic science as the theory of logistics, management, finance, and economic theory, etc. It has been proven that a number of factors influence digital processes in a logistics ecosystem, as in a socio-economic system. The main drivers for the development of digital processes in logistics networks are the cheapening of sensors and mobile communication systems that allow the collection and transmission of a huge amount of data from all of the participants in the supply chain. A networked look at an intelligent digital supply chain focuses on building resilience against potential external influences on the supply chain [64-68].

The use of a complex mathematical modeling apparatus is fundamentally important at the present stage, because today many supply chains are being transformed from a static sequence into a dynamic, interconnected system-a digital supply network-a term that characterizes the growing potential of reaching a network of partners in an ecosystem that ultimately reaches an optimal state. Digital supply chains collect information from different sources and locations for physical production and distribution process control. This is the uncontested direction of both logistics and the theory of innovation from the point of view of the concept of Industry 4.0.

\section{Conclusions}

The efficient functioning of the transport and logistics systems is of key importance for the BRICS countries in the field of international trade and integration into global production chains. They contribute significantly to the acceleration of growth and the reduction of costs. Cooperation between the BRICS countries should be aimed at the development of transport, information and communication infrastructure, as well as their supporting mechanisms. Among the main ones, the organizational, technological and informational mechanisms should be noted. Organizational and technological mechanisms include: the development of transport and communication infrastructure; the search for technological, design and legal solutions in order to create new international transport corridors in the territory of the BRICS countries; the application of innovative technologies to improve the efficiency of transport and logistics systems; the promotion of energy efficiency and emissions reduction in the transport sector; the creation of conditions for the use of standardized electronic data exchange systems in logistics to facilitate multimodal and intermodal transport in the BRICS countries; the cooperation and promotion of the use of technologies for ensuring traffic safety, transportation and infrastructure design, operation and monitoring; the harmonization of the operation of transport and logistics 
systems for the smooth movement of goods and passengers between the BRICS countries, including through the use of information and communication technology (ICT) tools; and cooperation in the development of skills in the design, construction and maintenance of infrastructure facilities.

The information mechanisms of interaction between the BRICS countries include: the exchange of information on measures and programs in the field of transport and logistics policy, and the approval of relevant long-term cooperation programs; the exchange of experience in the development and use of innovative communication equipment, especially intelligent transport systems and satellite navigation systems; establishing business dialogue in order to develop mechanisms for cooperation and the exchange of best practices; the implementation of joint research programs in the areas of content and application development, and the creation of networks of training centers in the field of information and communication technologies; sharing experiences and best practices regarding efficient urban transport systems, dynamic traffic control systems and efficient freight transport systems, and providing quality passenger services, etc.

The scientific contributions of our research are: for the first time, we conducted a comparative analysis of the level of logistics infrastructure development in the BRICS countries; for the first time, we presented the description of digital logistics platforms in the BRICS countries and conducted their comparative analysis; for the first time, we developed and proposed an analytical description of a DLP for the BRICS countries. This DLP can become a tool for increasing the level of economic integration, as well as the efficiency of the logistics, trade and economic interaction of the BRICS countries. The creation of the BRICS digital logistics platform will positively affect the solution of all of the above tasks of BRICS cooperation in the organizational, technological and informational aspects. The unified management created by the BRICS digital logistics platform, based on standardized algorithms, will make it possible to smooth out the difference in the logistics levels in the BRICS countries, which varies significantly according to the estimates by the LPI. The BRICS DLP will increase economic performance by reducing costs, choosing the optimal intertransport interaction, observing the conditions for keeping goods, and taking into account the risks associated with the limited periods of the storage of goods and transportation. On its basis of M2M interaction algorithms, it will be possible to monitor online the location as well as the condition of goods along the entire logistic leg, and to notify the receiving services about the arrival of goods, unloading and warehouse operations. In addition, in parallel, payments can be made for both freight forwarding services and customs duties, excise taxes and other payments associated with the movement of goods, automatically, in real time. These are all of the factors that relate to the issues of increasing the efficiency of transport infrastructure, logistics and communication, aimed at optimizing supply chains, creating new international digital transport corridors in the territory of the BRICS countries, infrastructure design, functioning, and the monitoring of the movement of goods and cargo. In general, the implementation of the BRICS DLP will provide a powerful tool for the management of transport and logistics activities, will bring a competitive advantage and, accordingly, an economic effect. This will serve as an additional factor in the economic growth and international cooperation among the BRICS countries.

Author Contributions: All authors contributed substantially to the entirety of the work reported. I.V.K. performed the project administration, E.V.K. provided supervision, S.M.S. prepared a conceptualization, A.A. performed the data curation, V.K.Y. prepared the formal analysis, D.S. contributed to the validation, and S.E.B. developed the methodology and edited the manuscript. The authors would like to thank the four anonymous referees for their very useful suggestions. All authors have read and agreed to the published version of the manuscript.

Funding: Authors 1-5 performed the study which was funded by RFBR according to the research project No 20-014-760 00029.

Institutional Review Board Statement: Not applicable.

Informed Consent Statement: Not applicable. 


\section{Data Availability Statement: Not applicable.}

Conflicts of Interest: The authors confirm that there is no conflict of interests to declare for this publication.

\section{References}

1. Grigoriev, L.; Pavlyushina, V.; Muzychenko, E.; Kheifets, E.; Kheifets, E. Mutual Trade of the BRICS Countries. Bulletin on Current Trends in the World Economy; Analytical Center of the Russian Federation Government: Moscow, Russia, 2020.

2. Trade Map. Trade Statistics for International Business Development. Available online: https://www.trademap.org/Index.aspx (accessed on 15 July 2021).

3. Hayaloglu, P. The Impact of Developments in the Logistics Sector on Economic. Int. J. Econ. Financ. Issues 2015, 5, 523-530.

4. Egert, B.; Kozluk, T.; Sutherland, D. Infrastructure and Growth: Empirical Evidence; William Davidson Institute Working Papers; WDI Publishing: Ann Arbor, MI, USA, 2009.

5. Berechman, J.; Ozmen, D.; Ozbay, K. Empirical analysis of transportation investment and economic development at state, county, and municipality levels. Transportation 2006, 33, 537-551. [CrossRef]

6. Yuan, H.; Kuang, J. The Relationship between Regional Logistics and Economic Growth Based on Panel Data. In Proceedings of the ICLEM 2010, Chengdu, China, 8-10 October 2010; pp. 618-623.

7. Cheng, G.P.; Liu, W.; Xie, C.W.; Zhou, J.Y. The Contribution of Logistics Industry to Economic Growth Based on Logistics Model. In Proceedings of the 2010 International Conference of Information Science and Management Engineering, Xi'an, China, 7-8 August 2010; Volume 2, pp. 489-492.

8. Chu, Z. Logistics and economic growth: A panel data approach. Ann. Reg. Sci. 2011, 49, 87-102. [CrossRef]

9. Démurger, S. Infrastructure Development and Economic Growth: An Explanation for Regional Disparities in China? J. Comp. Econ. 2001, 29, 95-117. [CrossRef]

10. McKinnon, A.; Brewer, A.M.; Button, K.J.; Hensher, D.A. Integrated Logistics Strategies. In Handbook of Transport Modelling; Emerald Group Publishing Limited: Emerald, Bingley, 2008; Volume 2, pp. 157-170.

11. BRICS Join Statistic Publication; Statistics South Africa: Pretoria, South Africa, 2018; ISBN 978-0-621-46599-0.

12. Stewart, W. Physical distribution: Key to improved volume and profits. J. Mark. 1965, 29, 65-70. [CrossRef]

13. McKinnon, A.C. Physical Distribution Systems; Routledge: London, UK, 1989.

14. Bowersox, D.J. Logistical Management; Macmillan: New York, NY, USA, 1978.

15. Bowersox, D.J.; Daugherty, P.J.; Droge, C.L.; Rogers, D.S.; Wardlow, D.L. Leading edge logistics: Competitive positioning for the 1990s. In Oak Brook; Council of Logistics Management: Lombard, IL, USA, 1989.

16. Stevens, G.C. Integrating the supply chain. Int. J. Phys. Distrib. Logist. Manag. 1989, 19, 3-8. [CrossRef]

17. Cooper, J.C.; Johnston, M. Dedicated contract distribution: An assessment of the UK market place. Int. J. Phys. Distrib. Logist. Manag. 1990, 20, 25-31. [CrossRef]

18. Scott, C.; Wesbrook, R. New strategic tools for supply chain management. Int. J. Phys. Distrib. Logist. Manag. 1991, 21, 23-33. [CrossRef]

19. Lambert, D.; Stock, J.R. Strategic Logistics Management, 3rd ed.; Homewood: Irwin, CA, USA, 1993.

20. Hammer, M.; Champy, J. Re-Engineering the Corporation: A Manifesto for Business Revolution; Nicholas Brealey: London, UK, 1993.

21. Morash, E.A.; Dröge, C.; Vickery, S. Boundary spanning interfaces between logistics, production, marketing and new product development. Int. J. Phys. Distrib. Logist. Manag. 1996, 26, 43-62. [CrossRef]

22. Christopher, M.C. Logistics and Supply Chain Management, 2nd ed.; Pearson Education Limited: London, UK, 1998.

23. Bowersox, D.J.; Closs, D.J. Logistical Management: The Integrated Supply Chain Process; McGraw-Hill Companies: New York, NY, USA, 1996; ISBN 9780070068834.

24. Lewis, J.C.; Naim, M.M.; Towill, D.R. An integrated approach to re-engineering material and logistics control. Int. J. Phys. Distrib. Logist. Manag. 1997, 27, 197-209. [CrossRef]

25. Aldin, N.; Stahre, F. Electronic commerce, marketing channels and logistics platforms-A wholesaler perspective. Eur. J. Oper. Res. 2003, 144, 270-279. [CrossRef]

26. Abrahamsson, M.; Aldin, N.; Stahre, F. Logistics platforms for improved strategic flexibility. Int. J. Logist. Res. Appl. 2003, 6, 85-106. [CrossRef]

27. Cambra-Fierro, J.J.; Ruiz-Benitez, R. Advantages of intermodal logistics platforms: Insights from a Spanish platform. Supply Chain Manag. 2009, 14, 418-421. [CrossRef]

28. Leal, E.; Salas, G. Logistics Platforms: Conceptual Elements and the Eole of the Public Sector; United Nations ECLAC Bull.: Santiago, Chile, 2009; pp. 1-9.

29. Vancza, J.; Egri, P.; Karnok, D. Planningin concert: A logistics platform for production networks. Int. J. Comput. Integr. Manuf. 2010, 23, 297-307. [CrossRef]

30. Ivanov, D.A. Strategic Cooperation; Vershina: Moskow, Russia, 2006.

31. Karnaukhov, S.B. Management of logistics infrastructure in Russia. Financ. Life 2012, 4, 48-54.

32. Dunaev, O.N.; Nesterova, D.V. Translogistic platform in the development of Euro-Asian air transport links. Transp. Russ. Fed. 2015, 6, 20-25.

33. Korchagina, E.; Bochkarev, A.; Bochkarev, P.; Barykin, S.; Suvorova, S. The treatment of optimizing container transportation dynamic programming and planning. E3S Web Conf. 2019, 135, 02016. [CrossRef] 
34. Korchagina, E.; Bochkarev, A.; Bochkarev, P.; Barykin, S. The Optimizing Container Transportation Dynamic Linear Programming Model. In VIII International Scientific Siberian Transport Forum. TransSiberia Advances in Intelligent Systems and Computing; Popovic, Z., Manakov, A., Breskich, V., Eds.; Springer: Berlin/Heidelberg, Germany, 2020; pp. 1043-1053. ISBN 978-3-030-37919-3.

35. Korchagina, E.; Naumova, E.; Kryukova, K.; Bakharev, V. Research of innovations implementation within the seaport anti-crisis policy. E3S Web Conf. 2019, 135, 04074. [CrossRef]

36. Korchagina, E.; Desfonteines, L. Internal resources of increasing retail efficiency. Intellect. Econ. 2019, 13, 122-130. [CrossRef]

37. Desfonteines, L.; Korchagina, E.; Evgrafov, A.; Khnykina, T.; Karmanova, A.; Semenova, Y. The Future of Information Technology in the Russian Trade. IOP Conf. Series Mater. Sci. Eng. 2020, 940, 12058. [CrossRef]

38. Teodorescu, M.; Korchagina, E. Applying Blockchain in the Modern Supply Chain Management: Its Implication on Open Innovation. J. Open Innov. Technol. Mark. Complex. 2021, 7, 80. [CrossRef]

39. Subramanian, N.; Chaudhuri, A.; Kayıkc1, Y. Blockchain Applications in Retail Supply Chain. In Blockchain and Supply Chain Logistics; Springer International Publishing: Berlin/Heidelberg, Germany, 2020; pp. 49-56.

40. Azzi, R.; Chamoun, R.K.; Sokhn, M. The power of a blockchain-based supply chain. Comput. Ind. Eng. 2019, 135, 582-592. [CrossRef]

41. Niforos, M. Beyond Fintech: Leveraging Blockchain for More Sustainable and Inclusive Supply Chains; International Finance Corporation (IFC) EM Compass Note; The World Bank: Washington, DC, USA, 2017.

42. Koh, L.; Orzes, G.; Jia, F. The fourth industrial revolution (Industry 4.0): Technologies disruption on operations and supply chain management. Int. J. Oper. Prod. Manag. 2019, 39, 817-828. [CrossRef]

43. Chaveesuk, S.; Khalid, B.; Chaiyasoonthorn, W. Understanding Stakeholders Needs for Using Blockchain Based Smart Contracts in Construction Industry of Thailand: Extended TAM Framework. In Proceedings of the 2020 13th International Conference on Human System Interaction (HSI), Tokyo, Japan, 6-8 June 2020; pp. 137-141. [CrossRef]

44. Rietveld, J.; Schilling, M.A. Platform Competition: A Systematic and Interdisciplinary Review of the Literature. J. Manag. 2020, 20, 014920632096979. [CrossRef]

45. Muangmee, C.; Kot, S.; Meekaewkunchorn, N.; Kassakorn, N.; Khalid, B. Factors Determining the Behavioral Intention of Using Food Delivery Apps during COVID-19 Pandemics. J. Theor. Appl. Electron. Commer. Res. 2021, 16, 1297-1310. [CrossRef]

46. Nathan, R.J.; Victor, V.; Gan, C.L.; Kot, S. Electronic commerce for home-based businesses in emerging and developed economy. Eurasian Bus. Rev. 2019, 9, 463-483. [CrossRef]

47. Scholten, K.; Stevenson, M.; van Donk, D.P. Dealing with the unpredictable: Supply chain resilience. Int. J. Oper. Prod. Manag. 2019, 40, 1-10. [CrossRef]

48. Remko, V.H. Research opportunities for a more resilient post-COVID-19 supply chain-Closing the gap between research findings and industry practice. Int. J. Oper. Prod. Manag. 2020, 40, 341-355. [CrossRef]

49. Utami, I.D.; Novianti, T. Sustainable Entrepreneurship Strategies for Salt Entrepreneurs in New Normal Business Concept. J. Ilm. Tek. Ind. 2021, 20, 101-108. [CrossRef]

50. Korchagina, E.; Kalinina, O.; Burova, A.; Ostrovskaya, N. Main logistics digitalization features for business. E3S Web Conf. 2020, 164, 10023. [CrossRef]

51. LPI Global Rankings 2018. Available online: https:/ /lpi.worldbank.org/international/global (accessed on 15 July 2021).

52. National Transport and Logistics Information Platform in China. Available online: www.logink.org (accessed on 15 July 2021).

53. China Communications Logistics LOGINK System. Available online: http://www.transformcn.com/Topics_En/2018-01/04 / content_136089.htm (accessed on 15 July 2021).

54. GLP. Available online: www.glp.com (accessed on 15 July 2021).

55. Brazil Transportation Startup CargoX Raises $\$ 80 \mathrm{mln}$ from Liechtenstein Fund. Available online: https: / finance.yahoo.com/ news/brazil-transportation-startup-cargox-raises-191229801.html?tsrc=rss\&guccounter=1 (accessed on 15 July 2021).

56. Twill. Available online: https:/ / www.twill.net/ (accessed on 15 July 2021).

57. Zamkov, A.S. Digital Platform will Unite all Services for Transport and Logistics in Russia. Available online: https://www. dtla.ru/news/anton-zamkov-edinaya-tsifrovaya-platforma-obedinit-vse-servisy-dlya-transporta-i-logistiki-rossii (accessed on 15 July 2021).

58. iFreightBox. Available online: https://www.ifreightbox.com (accessed on 15 July 2021).

59. Saloodo Digital Freight Platform. Available online: https: / / www.saloodo.com (accessed on 15 July 2021).

60. Ministry of Transport of the Russian Federation. Available online: https://mintrans.gov.ru/press-center/news/9352 (accessed on 15 July 2021).

61. Barykin, S.Y.; Kapustina, I.V.; Sergeev, S.M.; Kalinina, O.V.; Vilken, V.V.; Putikhin, Y.Y.; Volkova, L.V. Developing the physical distribution digital twin model within the trade network. Acad. Strateg. Manag. J. 2021, 20, 1-24.

62. Barykin, S.Y.; Bochkarev, A.A.; Dobronravin, E.; Sergeev, S.M. The place and role of digital twin in supply chain management. Acad. Strateg. Manag. J. 2021, 20,1-19.

63. Barykin, S.Y.; Kalinina, O.V.; Kapustina, I.V.; Dubolazov, V.A.; Esquivel, C.A.N.; Nazarova, E.A.; Sharapaev, P.A. The sharing economy and digital logistics in retail chains: Opportunities and threats. Acad. Strateg. Manag. J. 2021, 20, 1-14.

64. Nie, D.; Panfilova, E.; Samusenkov, V.; Mikhaylov, A. E-Learning Financing Models in Russia for Sustainable Development. Sustainability 2020, 12, 4412. [CrossRef]

65. An, J.; Mikhaylov, A.; Richter, U.H. Trade war effects: Evidence from sectors of energy and resources in Africa. Heliyon 2020, 6, e05693. [CrossRef] [PubMed] 
66. An, J.; Mikhaylov, A.; Jung, S.-U. A Linear Programming approach for robust network revenue management in the airline industry. J. Air Transp. Manag. 2021, 91, 101979. [CrossRef]

67. Chaiyasoonthorn, W.; Khalid, B.; Chaveesuk, S. Success of Smart Cities Development with Community's Acceptance of New Technologies. In Proceedings of the 9th International Conference on Information Communication and Management, Prague, Czech Republic, 23-26 August 2019; pp. 106-111. [CrossRef]

68. Hussain, H.I.; Kot, S.; Kamarudin, F.; Yee, L.H. Impact of Rule of Law and Government Size to the Microfinance Efficiency. Econ. Res. Ekon. Istraživanja 2021, 34, 1870-1895. [CrossRef] 